\title{
PROFILE OF COMMUNITY UNDERSTANDING AND LITERACY ABOUT DISASTER RISK MITIGATION: THE RESPONSES OF JAVA SOUTH COAST COMMUNITY AGAINST MEGATHRUST EARTHQUAKE AND TSUNAMI PREDICTION
}

\author{
Iqbal Ainur Rizki ${ }^{1}$, Handoko Bintoro ${ }^{1}$, Khoirun Nisa' ${ }^{1}$, Prima Rahman ${ }^{2}$, Arie Realita ${ }^{1}$, Utama Alan Deta ${ }^{1, *}$ \\ ${ }^{1}$ Department of Physics, Universitas Negeri Surabaya \\ ${ }^{2}$ Department of Geography Education, Universitas Negeri Surabaya \\ *Email: utamadeta@unesa.ac.id
}

\begin{abstract}
Widiyantoro et al., as Institut Teknologi Bandung (ITB) scientists, predict the worst possibility that in the south of Java Island, a megathrust earthquake with a maximum magnitude of up to 9.1 on the Richter scale and a tsunami of up to 20 meters. So understanding and literacy about mitigation of the megathrust earthquake and tsunami need to be improved so that the South Coast of Java Island (Pansela) community has prepared for these disasters. This study aims to analyze the understanding and literacy of the Pansela community of the earthquake and tsunami disaster against the predictions made by ITB scientists. This study uses a qualitative descriptive method with a total of 57 community respondents living in Pansela. The study results show that most communities believe in this prediction and have fewer mitigation efforts against this disaster. However, the respondents still did not know the specifics of the megathrust earthquake. They considered an earthquake in the south of Java Island related to the megathrust earthquake. Therefore, it is necessary to increase community understanding and literacy regarding mitigation efforts against megathrust earthquakes and tsunami.
\end{abstract}

Keywords: Megathrust Earthquake; Tsunami; ITB Scientists; Understanding; Mitigation.

\section{A. INTRODUCTION}

Java Island is very vulnerable to earthquakes and tsunamis because about $500 \mathrm{~km}$ from the South Coast of Java Island (Pansela) is a megathrust zone formed by the Indian Ocean plate subducting the Asian continent plate (Mulia et al., 2019; Priadi et al., 2020). This causes the occurrence of many earthquakes in the waters south of the island of Java. Based on the catalog of earthquakes and tsunamis by the Meteorology, Climatology and Geophysics Agency (BMKG) was noted that since 1700 the megathrust zone south of Java had occurred several times with significant earthquakes and great earthquakes. Large earthquakes with a magnitude of 7.0 have appeared eight times (Setiyono et al., 2019). In addition to earthquakes, the BMKG tsunami catalog also notes that tsunamis have occurred six times in the south of Java (Triyono et al., 2019).

So that the island of Java, which incidentally is the island with the highest population density in Indonesia, has a significant threat to earthquake and tsunami disasters, especially the southern 
area of Java. This has attracted several researchers to research the potential threat of earthquakes and tsunamis. The results of these studies can be used as a reference in conducting disaster risk mitigation. One of the studies that have attracted the community's attention to viral in the mass media was the research by Widiyantoro $e t$ $a l$. as scientists from the Institut Teknologi Bandung (ITB) (Widiyantoro et al., 2020).

This research states that the worstcase scenario if megathrust segments along Java rupture simultaneously indicate an earthquake with a maximum potential

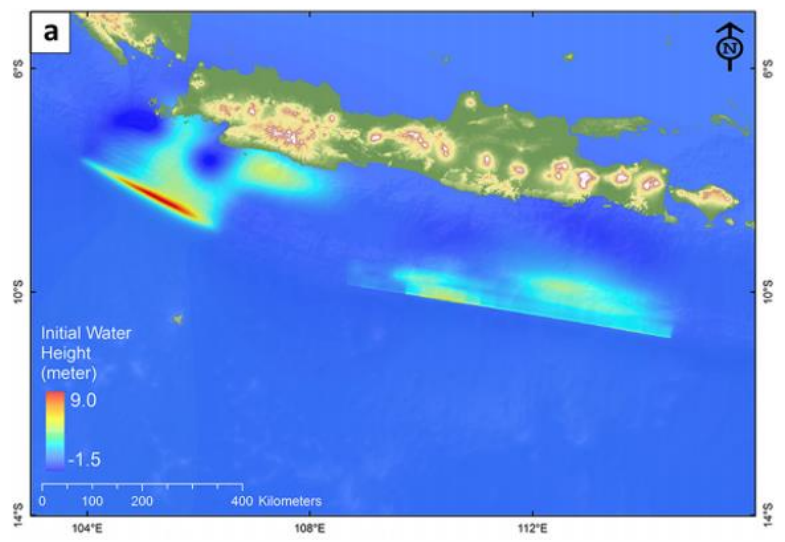

(a) magnitude of 9.1 and a tsunami with a height of up to 20 meters south coast of West Java and 12 meters south of East Java, as shown in Figure 1. The BMKG monitoring results also show that the megathrust zone south of Java is indeed very active (Setiyono et al., 2019). Several other studies related to the threat of earthquakes and paleotsunami have also confirmed traces of repeated earthquakes and tsunamis in southern Java in the past (Ammon et al., 2006; Soehaimi, 2008; Priyowidodo and Luik, 2013; Stuart, 2018).

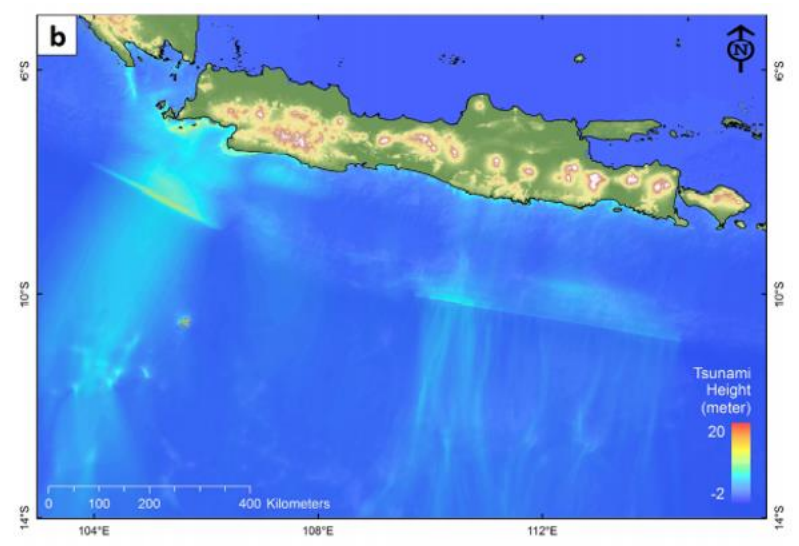

(b)

Figure 1. (a) Tsunami modeling results based on scenario 1 (earthquake in West Java segment 8.9 Mw) and scenario 2 (Earthquake in East Java and Central Java segments $8.8 \mathrm{Mw}$ );

(b) Maximum tsunami height modeling results based on results research by (Widiyantoro et al., 2020)

The many phenomena of an earthquake and tsunami on the island of Java and the prediction of megathrust earthquakes must be taken seriously by various parties, especially communities in earthquake potential areas. One way to improve community preparedness is to increase understanding and literacy regarding earthquake and tsunami risk mitigation (Kanbara et al., 2016; Afrian and Islami, 2019; Fadilah et al., 2021). This becomes very important to minimize the loss of property and life. Understanding and literacy about disasters are efforts to raise community awareness in dealing with a disaster. Meanwhile, 
information literacy regarding natural disasters involves finding, collecting, and evaluating then using the disaster information to mitigate the disaster (Marlyono, Pasya, and Nandi, 2016).

Mitigation regarding earthquake and tsunami disasters is crucial for the community to understand, especially for the Pansela community, which is predicted to have megathrust earthquakes and large tsunamis. According to a survey on the occurrence of the Hanshin-Awaji earthquake in Japan in 1995, it showed that more than $65 \%$ of mitigation efforts survived because of the rescue of self, family, and close relatives (Japan Association for Fire Science and Engineering, 1996). So that knowledge about disaster mitigation is significant for ourselves and close relatives.

Previously, research was done by (Marlyono, Pasya and Nandi, 2016; Marlyono and Nandi, 2018; Muslim et al., 2019; Deta et al., 2020), which discusses the profile of Java's community preparedness for earthquakes just in general. (Hall et al., 2017; Nugroho, 2019) studies the profile of the awareness of the people of the island of Java against tsunamis. These studies are still not up-todate on earthquake predictions by ITB scientists and do not study based on their location of residence. In fact, the magnitude of the earthquake and tsunami predicted was much greater than the general earthquake, so that the level of preparedness and awareness would be different. In addition, the impact of the earthquake and tsunami will be much greater on the people living on the coast. So that, it needs to analyze specific and actual to find the best solution and action to avoid the risk.

Therefore, this study will discuss the understanding and literacy skills of the Pansela community regarding earthquake and tsunami mitigation risk to respond to the predictions of megathrust earthquakes and tsunamis put forward by ITB scientists. This study aims to analyze the understanding and literacy of the Pansela community of the earthquake and tsunami disaster associated with the predictions made by ITB scientists. By analyzing the Pansela community's understanding and literacy regarding the megathrust earthquake and tsunami, it can be seen what actions can be taken to mitigate the impact of the megathrust earthquake and tsunami as predicted.

\section{B. MATERIALS AND METHODS}

The research method used is a written interview method by distributing the instrument in the form of a questionnaire. The questionnaire contains 
five questions that represent the into questionnaire questions as shown in

understanding and preparedness of the community in responding to disaster predictions by ITB scientists. The process of preparing the questionnaire is based on a grid of questionnaires made by arranging items through the description of the variables and indicators used, then written
Table 1. The data obtained is qualitative, so it does not require the validity and reliability of the questionnaire instrument (Deta et al., 2021). So those qualitative methods are used to build an understanding of the disaster literacy of the South Coast of Java community well.

Table 1. Variables, indicators, and question formulations used in this research

\begin{tabular}{|c|c|c|c|}
\hline No & Variables & Indicators & Formulation of the Question \\
\hline 1 & Literacy & $\begin{array}{l}\text { Respondents' literacy regarding } \\
\text { the information on the } \\
\text { megathrust earthquake and } \\
\text { tsunami circulating in the mass } \\
\text { media in terms of information } \\
\text { literacy } \\
\text { Respondents' literacy regarding } \\
\text { the circulated information about } \\
\text { megathrust earthquake and } \\
\text { tsunami from a scientific point of } \\
\text { view }\end{array}$ & $\begin{array}{l}\text { Do you know information that } \\
\text { scientists from ITB predict a } \\
\text { megathrust earthquake and } \\
\text { tsunami as high as } 20 \text { meters that } \\
\text { will occur on the south coast of } \\
\text { Java? } \\
\text { How do you respond to these } \\
\text { predictions or expressions? }\end{array}$ \\
\hline 2 & Understanding & $\begin{array}{l}\text { Respondents' understanding of } \\
\text { the megathrust earthquake and } \\
\text { tsunami } \\
\text { Respondents' understanding of } \\
\text { the megathrust and tsunami } \\
\text { mitigation efforts }\end{array}$ & $\begin{array}{l}\text { What do you know about the } \\
\text { megathrust earthquake and } \\
\text { tsunami? } \\
\text { What mitigation or prevention } \\
\text { efforts will you take to deal with } \\
\text { these predictions? }\end{array}$ \\
\hline & & $\begin{array}{l}\text { Respondents' understanding of } \\
\text { the relationship between } \\
\text { earthquakes that have occurred } \\
\text { and the predicted megathrust } \\
\text { earthquake }\end{array}$ & $\begin{array}{l}\text { On October } 25 \text { and } 26,2020 \text {, an } \\
\text { earthquake occurred in the } \\
\text { southern part of West Java with a } \\
5,9 \text { and } 4.5 \text { magnitude (strength) } \\
\text { with an epicenter, as shown in } \\
\text { Figure } 7 . \\
\text { Based on that earthquakes, what } \\
\text { is your opinion regarding the } \\
\text { relationship between that } \\
\text { earthquake and the megathrust } \\
\text { earthquake predicted by ITB } \\
\text { scientists? }\end{array}$ \\
\hline
\end{tabular}


The distribution of the questionnaire was carried out online on October 31 December 6, 2020, targeting the community of the South Coast of Java Island. The coastal areas of the island of Java include the Regencies/Cities of Pandeglang, Lebak, Sukabumi, Cianjur, Garut, Tasikmalaya, Ciamis, Pangandaran, Cilacap, Kebumen, Purworejo, Kulonprogo, Bantul, Gunungkidul, Wonogiri, Pacitan, Malang, Tulungagung, Blitar, Lumajang, Jember, Malang, and Trenggalek. The research sample obtained was 99 community consisting of 57 community respondents living in the South Coast area and 42 respondents living in non-South Coast areas.

The data analysis technique in this research is descriptive qualitative data analysis. This analysis was carried out by analyzing, describing, and summarizing various situations and conditions from multiple data collected from the results of Pansela community interviews regarding the problems studied (Tuerah, 2014; Suprapto et al., 2018). There were 57 respondents from several areas that became the focus of this research.

\section{RESULTS AND DISCUSSION}

Based on the results of the data sorting that has been carried out, several groupings of respondents were obtained. It was found that respondents are dominated by high school graduates as much as $56 \%$, student status 63\%, and living in the lowlands $44 \%$. This is because the distribution of the questionnaire is done online so that the young community dominates the respondents because they are more familiar with gadgets (Emanuel, 2013).

The first question is about community knowledge regarding the information on potential megathrust earthquakes and tsunamis in Pansela. The answers from the respondents can be seen in Figure 2. The graph shows that most communities already know the information about the predictions that ITB scientists have made. This is in line with Priyowidodo's research that the Pansela community already knows the natural characteristics of a tsunami, originating from their ancestors from generation to generation (Afrian and Islami, 2019).

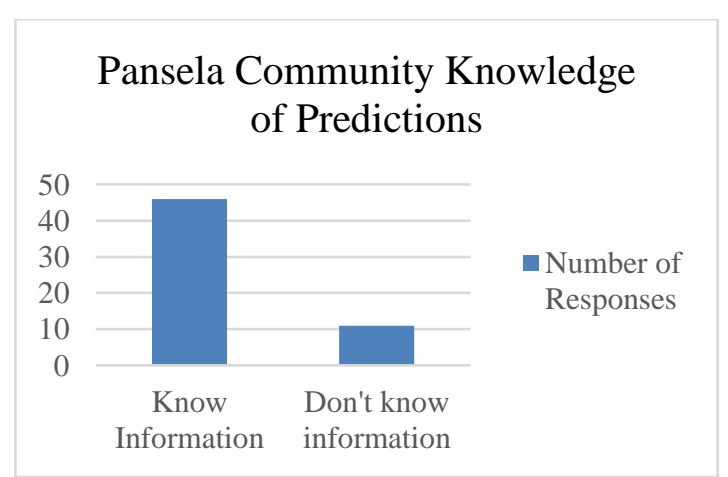

Figure 2. A bar chart of the knowledge of the Pansela Java community towards the predictions made by ITB scientists. 
The second question regarding their responses is related to the predictions made by ITB scientists. Opinions from respondents will be implicitly grouped into respondents' beliefs about these predictions, as shown in Figure 3. The diagram indicates that most communities believe in these predictions. However, some respondents still do not believe the scientific information. When viewed from the educational background, almost all respondents who do not believe the information have a high school education. This shows that the education level relatively does not affect a person's trust in scientifically proven information.

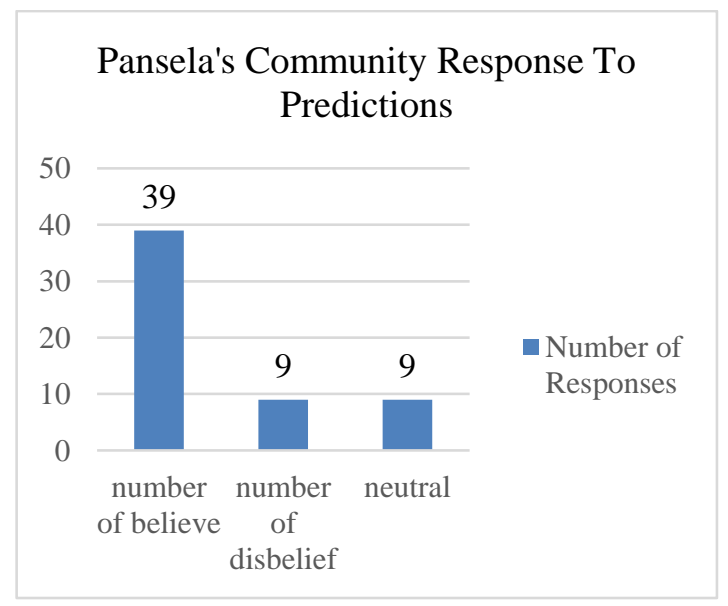

Figure 3. Bar chart regarding the response of the Pansela Java community to the predictions made by ITB scientists.

In this second question, most communities who believe in these predictions have anxiety but are still accompanied by vigilance and mitigation efforts. One of their answers was as follows:
"At first I must have been afraid because the area where I live is only about $5 \mathrm{~km}$ from the sea. However, I tried to use this information to urge people around me not to panic and stay alert and as much as possible avoid the beach area first." -LRPI

Based on the response above, it appears that the respondents believed the prediction of the megathrust earthquake and tsunami and tried to appeal to the community around them. However, the argument's weakness is not supported by a theoretical basis regarding the megathrust earthquake or tsunami itself. One opinion that is equipped with data or theoretical basis is as follows:

"Basically, Indonesia is a country located in the Pacific ring of fire which makes Indonesia a country that is prone to earthquakes and volcanic eruptions which in the future can also cause a tsunami. Regarding these predictions, we should increase our maximum preparedness to face whatever things will happen in the future."

In addition to answers that represent the respondents' agreement with the predictions made by ITB scientists, some answers represent disagreement with a unique response. One opinion that does not believe in the prediction is as follows. "I can't believe it, because as far as I know, there is still no tool to detect earthquakes accurately until now." The $S A$ 
The response above is quite unique because the argument is equipped with facts: no technology or equipment cannot detect earthquakes. BMKG often uses this fact to avoid fake news circulated in the community regarding earthquake predictions (Rachmawati, Kurniawan, and Mawaddah, 2020). According to the answers above, the misconception that occurs is that the earthquake prediction published by ITB scientists is the worstcase scenario of a megathrust earthquake and tsunami in Indonesia at an unknown time. Meanwhile, fake news (hoaxes) regarding earthquake predictions that circulate are usually accompanied by the time of the earthquake. In fact, until now, the time of the earthquake can't be predicted (Malau and Sitepu, 2016; Senthilkumar et al., 2020). This is presumably due to several factors: respondents who have not read the news about the full megathrust earthquake prediction or news publications in the mass media that do not write complete information (Kwanda and Lin, 2020).

The third question is about the community's understanding of the megathrust earthquake and tsunami. This question aims to determine the community's understanding of the megathrust earthquake and tsunami besfore they understand the mitigation efforts that must be carried out. The answers to this question will be grouped into several categories, namely: very understanding, quite understanding, less understanding, and not understanding.

Respondents are considered very understanding if they can explain in detail about the megathrust earthquake and tsunami well. One response was as follows:

"Megathrust earthquake is an event that occurs in a subduction zone at a destructive convergent plate boundary, where one tectonic plate is under pressure from another. This earthquake is the most powerful interplate earthquake on the planet, with a moment magnitude ( $\mathrm{Mw}$ ) that can exceed 9.0. Since 1900, earthquakes of magnitude 9.0 or greater are considered highmagnitude earthquakes. While a tsunami is a series of large waves caused by an earthquake on the seabed." -YB

Respondents are considered quite understanding if they can explain earthquakes and tsunamis in general. One response was as follows:

"A large earthquake that causes a fault in the earth's crustal plate in the sea, so that water enters the gap suddenly and forms a large sea wave." -FAS

Respondents are considered less understanding if they understand little information about the earthquake and 
tsunami. Some of the responses were as follows:

"A large earthquake that triggered a tsunami as high as $20 \mathrm{~m}$." -DK

"Large-scale earthquake while the tsunami rose sea levels due to a great earthquake." -II

Respondents are considered not to understand if they explicitly do not know about the megathrust earthquake and tsunami. Some of the responses are as follows:

"Don't know it" -AM

"Secret of nature"-US

"Don't know more yet" -EDS

Based on all respondents' answers, most of them fall into the category of quite understanding. However, respondents still do not know the specifics of megathrust earthquakes and mostly describe "huge earthquakes". Whereas according to (Faizah et al., 2019), megathrust earthquakes are destructive earthquakes caused by the movement of intercontinental plates colliding with each other, causing a powerful earthquake with a magnitude of up to $9.0 \mathrm{SR}$. While the tsunami is a tidal wave with a height of 8 $\mathrm{m}$ and can reach $30 \mathrm{~m}$ when approaching the port or land area (Nur, 2010). This finding is also similar to the research by Priyowidodo that the community, especially the Pacitan area, is quite aware of the tsunami itself (Priyowidodo and Luik, 2013).

The fourth question is, "What mitigation or prevention efforts will you take to deal with these predictions?". This question aims to see the extent of community mitigation efforts regarding the predictions made by ITB scientists. Respondents' opinions on this question will be grouped into four levels with the results as shown in Figure 4. Based on the graph, it can see that the community at most less knowledge about the mitigation efforts that will be carried out when the megathrust earthquake and tsunami happen. Similar to the research of Putri et al. (2018), which shows that the understanding of tsunami disaster risk mitigation for the community of Karanggadung Village, Kebumen Regency, is still less than $50 \%$ from predisaster to post-disaster.

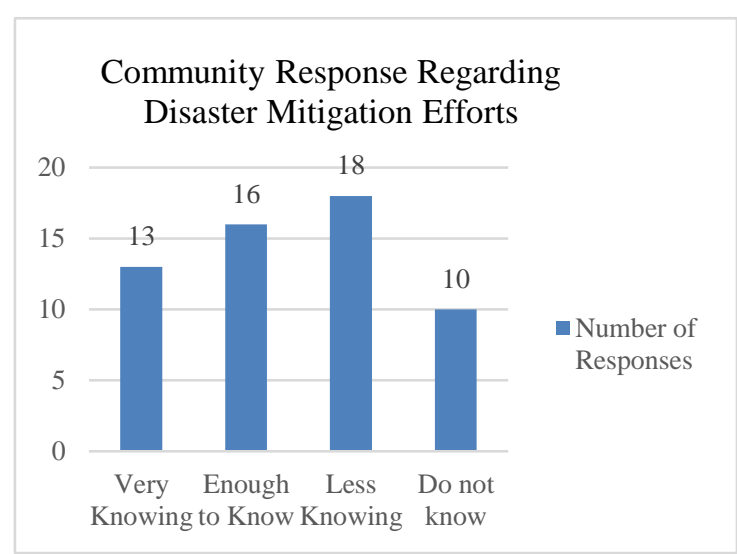

Figure 4. Bar chart of Java Island's Pansela community's mitigation efforts against predictions made by ITB scientists 
Respondents were considered very knowledgeable when they mentioned three or more efforts to be made. One of the responses that categorized knowing very well was as follows:

"Calm down and don't panic, prepare for maximum preparedness such as starting to reactivate one of the previous habits, namely kentongan as a source of disaster information, providing education to families and people around about this so that can be prepared at any time when this happens." -YB

Respondents are considered to know enough if they mention two efforts that must be made. Some responses that indicate this category are as follows:

"Before a disaster occurs I must know the route to a safe place. Prepare important files and necessities in one bag." -SA

"Pay attention to earthquake warnings or anticipate when an earthquake occurs by evacuating themselves to a higher place." -DR

Responses are considered less aware if they only mention one effort and are at least alert to mitigate earthquake and tsunami disasters, according to the predictions of ITB scientists. Some of the responses that indicate this category are as follows:
"We still have to be vigilant and don't panic." -MI

"Pray and keep looking for information." -ARJ

Respondents were considered not knowing if they answered that they did not know what to do. Some responses that indicate this category are as follows:

“Nothing, still relaxed." -HH

"I do not know what will be done to deal with these predictions." -AL

In the fifth question, the respondent responded regarding the earthquake's relationship on October 25 and 26, 2020, in the southern part of West Java with the megathrust earthquake predicted by ITB scientists. Almost all respondents believe that this earthquake is related to the megathrust earthquake predicted by ITB scientists. However, compared to the prediction map in Figure 1, the earthquake location has a difference. Megathrust earthquakes occur in the megathrust zone or subduction zone depicted in the red line in Figure 5 (Madden et al., 2021). While the epicenter of the earthquake that occurred on October 25 and 26 is still far from the megathrust zone. So there is no connection between the two earthquakes. Some of the opinions of respondents who believe that there is a link are as follows: 
"It is possible that the earthquake that occurred on October 25 and 26 was an earthquake caused by plate activity around the south coast of Java. If the predictions regarding the megathrust earthquake are correct, it is possible that the earthquake that occurred on October 25 and 26 was the beginning of the earthquake, so there may be aftershocks before the megathrust earthquake actually occurs." -FDN

"It is related where the prediction by the ITB scientists stated that a megathrust earthquake would occur in the south of West Java or East Java with several scenarios that have been explained very clearly by the ITB scientists themselves." -YB
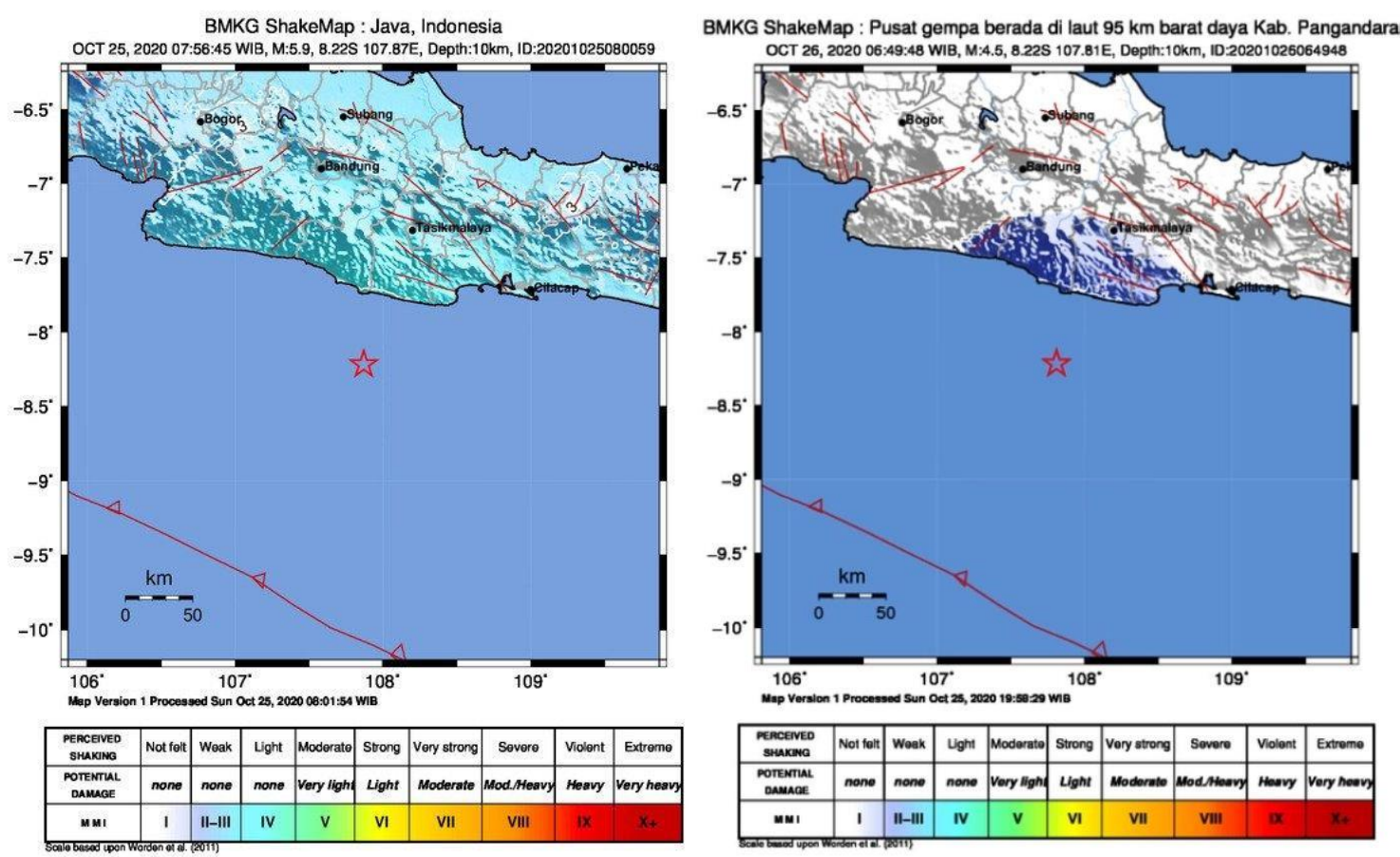

Figure 5. Two earthquakes occurred in the South of Java Island on October 25 and 26, 2020. These two earthquakes were included in the fifth question (Badan Meteorologi Klimatologi dan Geofisika, 2020).

In addition, there are several correct answers that there is no relation between the earthquake sources. They are as follows:

"There is no response to the relationship above. But basically Indonesia is in the ring of fire area, the earth plate under Indonesia is also very active.
The Indonesian people should be more aware of the potential disasters that will arise. Understand and prepare for disaster mitigation calmly and maturely. When a disaster occurs, the community is ready to face it." -SA

"There is no relation between the previous earthquake and the future one." -KK 
Overall, the community's understanding of megathrust earthquakes is still lacking. Therefore, further efforts are needed to improve knowledge of disaster mitigation to the community, especially the Pansela area regarding the megathrust earthquake and tsunami. Some things that can be done are to include disaster mitigation knowledge in the school curriculum, direct socialization to the community, make strategic policies by the government, provide mitigation guidelines to the community, and collaborate with various parties (Roskusumah, 2013; Bilal Habibie and Sjafei, 2017; Hariyono et al., 2018; Kastolani and Mainaki, 2018; Isna et al., 2019; Tamuntuan et al., 2019; Dian Agustina, Sunandi and Nugroho, 2020; Yousuf et al., 2020). So that they understand disaster mitigation, have vigilance, don't panic, and understand what to do when a disaster happened. Moreover, several city centers on the coast, such as Cilacap and Pacitan Regencies, are prone to casualties and material casualties (Probosiwi, 2013; Khasanah, Suwarsito and Sarjanti, 2014).

Nevertheless, it is necessary to appreciate the community mitigation efforts that will be carried out following the predictions of this ITB scientist. The survey results shown in Figure 6 show that some communities already understand the efforts to mitigate the megathrust earthquake and tsunami. The community is expected to understand the appropriate mitigation measures to minimize the impacts caused by the earthquake and tsunami disaster as predicted.

Research on disaster mitigation is significant because it is part of disaster risk management and control (Scolobig et al., 2015). Disaster management can be calculated through three components, namely, the risk of danger (hazard), vulnerability (vulnerability), and capability (capability) (Rafiq and Blaschke, 2012). Each of these components has characteristics and uses that are mutually sustainable to measure and determine disaster risk in an area. The factor of understanding and information literacy of the community is one part of the capability or ability to cope with disasters both materially and non-materially (Shohaya et al., 2013; Ali et al., 2019). Therefore, it is necessary to improve the quality of human resources in terms of knowledge and skills about disaster mitigation to minimize the risks posed by disasters.

This study has limitations, there are including connection between respondents and study criteria (only Pansela society), difficulty in conducting publications and 
inviting respondents to fill out forms, long process to gain more information from respondents using interview method, classify best answer of respondents fill form.

So there are recommendations, including: (1) Increase the number of respondents evenly for all areas of the island of Java; (2) Involving various parties to publish the questionnaire; and (3) Conduct additional interviews with respondents.

There is also a development from this research, namely: increasing the understanding and literacy of the Pansela community through various efforts according to research. After that, a posttest was conducted to understand the megathrust earthquake and tsunami as predicted by ITB scientists.

\section{CONCLUSIONS}

The Pansela community's understanding and literacy of earthquake and tsunami disaster information on the megathrust earthquake prediction by ITB scientists are lacking. Most communities believe in these predictions, but less knowledge about the mitigation efforts must do when the megathrust earthquake and tsunami happen. They still do not know the specifics of the megathrust earthquake and tsunami impact for them.
This information is very important for people who live there and it needs to be spread up through direct socialization, infographic poster, and other methods that they can understand. Nevertheless, it is necessary to appreciate the community's trust in predicting the megathrust earthquake and its mitigation efforts that will or have been carried out.

\section{E. REFERENCES}

Afrian, R. and Islami, Z. R. (2019) 'Peningkatan potensi mitigasi bencana dengan penguatan kemampuan literasi kebencanaan pada masyarakat Kota Langsa', Jurnal Pendidikan Geografi, 24(2), pp. 132-144. doi: 10.17977/um017v24i22019p132.

Ali, M. S. S. et al. (2019) 'Community based disaster management: Indonesian experience', IOP Conference Series: Earth and Environmental Science, 235(1). doi: 10.1088/1755-1315/235/1/012012.

Ammon, C. J. et al. (2006) 'The 17 July 2006 Java tsunami earthquake', Geophysical Research Letter, 33(24).

Badan Meteorologi Klimatologi dan Geofisika (2020) Earthquake Catalogue.

Deta, U. A. et al. (2020) 'The Scientific Argumentation Profile of Earthquake Mitigation of NonScience Undergraduate Student in Universitas Negeri Surabaya', Journal of Physics: Conference Series, 1467(1). doi: 10.1088/17426596/1467/1/012037.

Deta, U. A. et al. (2021) 'The Understanding and Awareness of First-Year Undergraduate Physics Students in Astronomical 
Phenomena: A Response of Penumbral Lunar Eclipses on June 5th, 2020', Journal of Physics: Conference Series, 1747(1). doi: 10.1088/1742-6596/1747/1/012039.

Dian Agustina, Sunandi, E. and Nugroho, S. (2020) 'Pendampingan Mitigasi Bencana Gempa Bumi dan Tsunami Berbasis Pengetahuan Lokal pada Masyarakat Rentan Bencana di Kabupaten Mukomuko Bengkulu', Engagement: Jurnal Pengabdian Kepada Masyarakat, 4(1), pp. 87$99 . \quad$ doi: 10.29062/engagement.v4i1.102.

Emanuel, R. C. (2013) 'The American college student cell phone survey', Coll Stud J, 47(1), pp. 75-81. Available at: http://ovidsp.ovid.com/ovidweb.cgi $? \mathrm{~T}=\mathrm{JS} \& \mathrm{PAGE}=$ reference $\& \mathrm{D}=\mathrm{psyc}$ $10 \& N E W S=N \& A N=2013-10664-$ 008.

Fadilah, M. et al. (2021) 'Disastervulnerable community perception related to pre-earthquake natural phenomena in west sumatera as part of disaster preparedness', IOP Conference Series: Earth and Environmental Science, 683(1). doi: 10.1088/1755-1315/683/1/012075.

Faizah, N., Cahyaningrum, D. and Herani, I. (2019) 'Kesehatan Mental Remaja Yang Tinggal Di Daerah Rawan Gempa Megathrust', in Prosiding Seminar Nasional \& Workshop Psikologi Klinis UM 2019. Malang: Universitas Negeri Malang, pp. 9398.

Habibie, M. B. and Sjafei, S. (2017) 'Mitigasi Bencana Tsunami Melalui Pariwisata (Studi Kasus di Situs Tsunami Kapal PLTD Apung Banda Aceh)', Pascasarjana Universitas Syiah Kuala, 6(2), p. 36.

Hall, S. et al. (2017) 'Awareness of tsunami natural warning signs and intended evacuation behaviors in Java, Indonesia', Natural Hazards,
89(1), pp. 473-496. doi: 10.1007/s11069-017-2975-3.

Hariyono, E. et al. (2018) 'Designing Geoscience Learning for Sustainable Development: A Professional Competency Assessment for Postgraduate Students in Science Education Program', Jurnal Penelitian Fisika dan Aplikasinya (JPFA), 8(2), p. 61. doi: 10.26740/jpfa.v8n2.p61-70.

Isna, B. U. et al. (2019) 'Development of OrSAEv Model Learning Materials to Strengthen the Characters of Tsunami Disaster Mitigation for Middle School Students (Preliminary Study)', Journal of Physics: Conference Series, 1417(1). doi: 10.1088/17426596/1417/1/012082.

Japan Association for Fire Science and Engineering (1996) Fire Investigation of Southern Earthquake in Hyogo Prefecture in 1995, Japan. Tokyo: J.A.F.S.E.

Kanbara, S. et al. (2016) 'Operational definition of disaster risk-reduction literacy', Health Emergency and Disaster Nursing, 3(1), pp. 1-8. doi: 10.24298/hedn.2014-0016.

Kastolani, W. and Mainaki, R. (2018) 'Does Educational Disaster Mitigation Need To Be Introduced In School?', SHS Web of Conferences, 42, p. 00063. doi: $10.1051 /$ shsconf/20184200063.

Khasanah, L. U., Suwarsito and Sarjanti, E. (2014) 'Tingkat Kerawanan Bencana Tsunami Kawasan Pantai Selatan Kabupaten Cilacap', Jurnal Geoedukasi, 3(2), pp. 77-82.

Kwanda, F. A. and Lin, T. T. C. (2020) 'Fake news practices in Indonesian newsrooms during and after the Palu earthquake: a hierarchy-ofinfluences approach', Information Communication and Society, 23(6), pp. 849-866. doi: 
10.1080/1369118X.2020.1759669.

Madden, E. H. et al. (2021) 'Linked 3-D modelling of megathrust earthquaketsunami events: From subduction to tsunami run up', Geophysical Journal International, 224(1), pp. 487-516. doi: 10.1093/gji/ggaa484.

Malau, N. D. and Sitepu, M. (2016) 'Peramalan Terjadinya Gempa Bumi Tektonik untuk Wilayah Pulau Nias Menggunakan Metode Distribusi Weibull dan Eksponensial', Jurnal EduMatSains, 1(1), pp. 15-28.

Marlyono, S. G. and Nandi, N. (2018) 'The Preparedness Level of Community in Facing Disaster in West Java Province', IOP Conference Series: Earth and Environmental Science, 145(1). doi: 10.1088/1755-1315/145/1/012103.

Marlyono, S. G., Pasya, G. K. and Nandi (2016) 'Peranan Literasi Informasi Bencana Terhadap Kesiapsiagaan Bencana Masyarakat Jawa Barat', Gea. Jurnal Pendidikan Geografi, 16(2), pp. 116-123.

Mulia, I. E. et al. (2019) An Optimized Array Configuration of Tsunami Observation Network Off Southern Java, Indonesia, Journal of Geophysical Research: Solid Earth. doi: 10.1029/2019JB017600.

Muslim, D. et al. (2019) 'Earthquake Hazard Perception of the Education Stakeholders in Sukabumi Regency, West Java, Indonesia', Journal of Physics: Conference Series, 1363(1). doi: 10.1088/17426596/1363/1/012022.

Nugroho, A. (2019) 'Model Pembelajaran Mitigasi Bencana Tsunami', in Prosiding Seminar Nasional Manajemen Bencana di Era Revolusi Industri 5.0. Puwrokerto, pp. 233-239.

Nur, A. M. (2010) 'Gempa Bumi, Tsunami Dan Mitigasinya', Jurnal Geografi, $\quad$ 7(1). doi: 10.15294/jg.v7i1.92.

Priadi, R. et al. (2020) 'Analysis of Tsunami Inundation due in Pangandaran Tsunami Earthquake in South Java Area Based on Finite Faults Solutions Model', Jurnal Penelitian Fisika dan Aplikasinya (JPFA), 10(02), pp. 114-124. doi: 10.26740/jpfa.v10n2.p114-124.

Priyowidodo, G. and Luik, J. E. (2013) 'Literasi Mitigasi Bencana Tsunami untuk Masyarakat Pesisir di Kabupaten Pacitan', Ekotrans, 13(1), pp. 47-61.

Probosiwi, R. (2013) 'Manajemen Risiko Tsunami Untuk Penataan Ruang', Jurnal TeknosainsTeknosains, 2(2), pp. 71-158.

Putri, N. A. E., Sanjoto, T. B. and Sriyanto (2018) 'Pendidikan Mitigasi Bencana Tsunami dengan Menggunakan Media Pembelajaran Buku Saku Pada Masyarakat Pesisir Desa Karanggadung Kecamatan Petanahan Kabupaten Kebumen', Edu Geography, 6(1), pp. 72-79. Available at: http://journal.unnes.ac.id/sju/index. php/edugeo.

Rachmawati, R., Kurniawan, R. and Mawaddah, M. (2020) 'Strategi Komunikasi Badan Meteorologi Klimatologi dan Geofisika (BMKG) Aceh Dalam Mengantisipasi Berita Hoax Gempa Aceh', Jurnal Peurawi : Media Kajian Komunikasi Islam, 1(1), pp. 20-36.

Rafiq, L. and Blaschke, T. (2012) 'Disaster risk and vulnerability in Pakistan at a district level', Geomatics, Natural Hazards and Risk, 3(4), pp. 324-341. doi: 10.1080/19475705.2011.626083.

Roskusumah, T. (2013) 'Komunikasi Mitigasi Bencana Oleh Badan Geologi Kesdm Di Gunung Api Merapi Prov. D. I. Yogyakarta', Jurnal Kajian Komunikasi, 1(1), pp. 
59-68. doi: 10.24198/jkk.vol1n1.6.

Scolobig, A. et al. (2015) 'Towards people-centred approaches for effective disaster risk management: Balancing rhetoric with reality', International Journal of Disaster Risk Reduction, 12, pp. 202-212. doi: 10.1016/j.ijdrr.2015.01.006.

Senthilkumar, M. et al. (2020) 'Earthquake prediction from high frequency groundwater level data: A case study from Gujarat, India', HydroResearch, 3, pp. 118-123. doi: 10.1016/j.hydres.2020.10.004.

Setiyono, U. et al. (2019) Katalog Gempa Bumi Signifikan dan Merusak 18212018, Pusat Gempabumi dan Tsunami Kedeputian Bidang Geofisika. Jakarta: Pusat Gempabumi dan Tsunami Kedeputian Bidang Geofisika. Available at: http://marefateadyan.nashriyat.ir/no de/150.

Shohaya, J. N. et al. (2013) 'Survey dan Analisis Seismisitas Wilayah Jawa Timur Berdasarkan Data Gempa Bumi Periode 1999-2013 Sebagai Upaya Mitigasi Bencana Gempa Bumi', Jurnal Penelitian Fisika dan Aplikasinya (JPFA), 3(2), pp. 18-27.

Soehaimi, A. (2008) 'Seismotektonik dan Potensi Kegempaan Wilayah Jawa', Indonesian Journal on Geoscience, 3(4), pp. 227-240. doi: 10.17014/ijog.vol3no4.20085.

Stuart, K. L. (2018) Discovery of Possible Paleotsunami Deposits in Pangandaran and Adipala, Java, Indonesia Using Grain Size, XRD, and 14C Analyses. Brigham Youth University.

Suprapto, N. et al. (2018) 'Pre-service physics teachers' understanding on total lunar eclipse: A response of supermoon on January 31 st 2018', Journal of Physics: Conference Series, 1108(1). doi: 10.1088/1742-
6596/1108/1/012097.

Tamuntuan, G., Pasau, G. and Takumansang, E. (2019) 'Peningkatan Kapasitas Masyarakat Untuk Kesiap-siagaan dan Mitigasi Bencana Tsunami di Desa Borgo Kabupaten Minahasa', VIVABIO: Jurnal Pengabdian Multidisiplin, 1(3), p. $1 . \quad$ doi: 10.35799/vivabio.1.3.2019.25442.

Triyono, R. et al. (2019) Katalog Tsunami Indonesia Per-Wilayah Tahun 4162018, Pusat Gempabumi dan Tsunami Kedeputian Bidang Geofisika. Jakarta: Pusat Gempabumi dan Tsunami Kedeputian Bidang Geofisika.

Tuerah, M. (2014) 'Analisis Pengendalian Persediaan Bahan Baku Ikan Tuna pada CV. Golden Kk', Jurnal Riset Ekonomi, Manajemen, Bisnis dan Akuntansi, 2(4), pp. 524-536.

Widiyantoro, S. et al. (2020) 'Implications for megathrust earthquakes and tsunamis from seismic gaps south of Java Indonesia', Scientific Reports, 10(1), pp. 1-11. doi: 10.1038/s41598-020-72142-z.

Yousuf, M. et al. (2020) 'Understanding and managing earthquake hazard visa viz disaster mitigation strategies in Kashmir valley, NW Himalaya', Progress in Disaster Science, 5, p. 100064. doi: 10.1016/j.pdisas.2020.100064. 